\title{
On the existence of iodine in freshwater plants
}

\section{Ad. Chatin}

To cite this article: M. Ad. Chatin (1850) On the existence of iodine in freshwater plants, Philosophical Magazine Series 3, 36:245, 486-487, DOI: 10.1080/14786445008646534

To link to this article: http://dx.doi.org/10.1080/14786445008646534

曲 Published online: 30 Apr 2009.

Submit your article to this journal

Џ Article views: 2

Q View related articles $₫$ 
difference between my left and right, from long habit of using microscopes, still the general result is similar in each, and I think such as must be detected by other persons.

I made a small square bounded by narrow lines on a sheet of paper, and closing my left eye, I observed that the image was double, the false one being raised, and to the left of the true the interval filled up with a pale reddish-brown spectrum, most intense near the true image; the breadth of the interral about 0.03 inch. With my right eye closed, the image was, as I expected, to the right and above (in both instances towards the brow and nose), and the interval similarly tinged, but fainter, and 0.025 inch wide.

I then took a slip of card, and made with a pen-knife a fine slit in it, and looked through it held horizontally at the square; the upper false image was no longer visible, the upper and lower sides of the square clearly defined, but the lateral sides were unchanged; on holding the slit vertically, the lateral false images disappeared and the upper and lower returned. Similar appearances occurred with the other eye.

I now took a card and made two fine pin-holes exactly in the positions of the centres of my pupils, and I found that I saw the true image as correctly as I had ever done in my life; in fact, it supplied the place of a pair of spectacles; the square, of course, being seen under a greater angle, appearing magnified. By making the pin-hole larger or smaller, the focal distance, if I may use the expression, increased or diminished proportionably. I beg further to remark, that in the sunshine I can read small print at the natural focal distance ; it is only in fainter light that the double image and confusion of letters occur. Now a flattening of the cornea won't explain all this: it seems to have a more intimate connexion with some want of contractility engendered in old age in the iris. I am curious to obtain an explanation, and send this notice to you for the purpose of eliciting one.

Truly yours,

R. T. Cranmore.

P.S. 1 have since observed that wire-gauze, the wire being very fine, and the meshes about $\frac{1}{50}$ th of an inch in diameter, when worn close to the eye, enables me to read small print with tolerable facility at a distance of five or six inches; when the meshes are closer, I can see the most minute objects with remarkable distinctness.
Brompton, May 4, 1850.
R. T. C.

\section{ON THE EXISTENCE OF IODINE IN FREShWATER PLANTS.}

BY M. AD. CHATIN.

In verifying the fact stated by Muller (Lindley's Vegetable Kingdom), of the existence of iodine in a cress of unknown origin, the author has ascertained-

That iodine exists in freshwater cresses, that it is not peculiar to this species, nor general with respect to plants of the family of the Cruciferæ;

That iodine does not exist, or at any rate cannot be discovered in terrestrial plants, whereas it exists in all aquatic plants ; 
That of the latter, those which occur in running water are richer in iodine than those of stagnant water;

That in sheets of water, which are sufficiently large to be strongly agitated by winds, the plants approach those of running water, in the quantity of iodine which they contain;

That the proportion of iodine contained in plants is in general independent of their nature, and subordinate only to their habitat, as indicated by the Confervæ, the Potamogetons, the Nymphæa, the Ranunculi, and the Cresses, all of which are equally rich in iodine in running waters, and equally poor in marshes;

That the iodine exists uncombined with the tissue, but in the state of alkaline iodide in the juice of the plant.-Comptes Rendus, Mars 25, 1850 .

METEOROLOGICAL OBSERVATIONS FOR APRIL 1850.

Chiswick.-A pril 1. Overcast : rain. 2. Cloudy : clear. 3. Fine : showery at night. 4. Boisterous, with rain. 5. Cloudy and rather boisterous : fine : clear. 6. Overcast. 7. Cloudy and fine. 8. Foggy : overcast: slight showers. 9. Cloudy. 10. Very fine. 11. Rain: showery: overcast. 12. Fine: hot sun : thunder commenced $\frac{1}{4}$ past 12 noon : overcast at night. 13. Hazy : rain. 14. Hazy : rain at night. 15. Rain : very heavy rain in forenoon : cloudy. 16. Showery. 17. Low white clouds: fine throughout. 18. Clear: very fine. 19. Rain. 20. Showery. 21. Slight rain : cloudy. 22. Fine : clear. 23. Overcast : cloudy. 24. Clear: fine. 25. Fine : overcast and cold : clear at night. 26. Cloudy and cold. 27. Fine, but cold. 28, 29. Cloudy : fine, but cold, with excessively dry air. 30. Fine : cloudy.

Mean temperature of the month $\ldots \ldots \ldots \ldots \ldots \ldots \ldots \ldots \ldots .48^{\circ} .41$

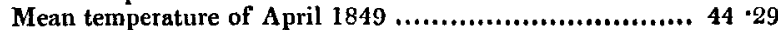

Mean temperature of A pril for the last twenty-four years ... $47 \cdot 53$

Average amount of rain in A pril ................................ 1.46 inch.

Boston.-April 1. Claudy. 2. Cloudy, rain P.M. 3. Fine. 4. Cloudy: rain A.M. 5. Cloudy. 6. Cloudy : rain P.M. 7. Cloudy. 8. Cloudy : rain A.M. and P.M. 9. Cloudy : rain P.M. 10. Fine. 11, 12. Cloudy. 13. Cloudy : rain P.M. 14. Cloudy. 15. Cloudy: rain early A.M. 16. Cloudy : rain A.M. and P.M. 17. Cloudy : rain. 18. Fine. 19. Cloudy : rain A.M. 20, 21. Cloudy: rain P.M. 22. Cloudy. 23. Cloudy : rain. 24. Cloudy. 25. Fine. 26-28. Cloudy. 29. Cloudy : rain P.M. 30. Cloudy.

Applegarth Manse, Dumfries-shire.-April 1, 2. Rain, moderate. 3. Rain : mild : heavy r.s. 4. Rain heavy during night: drizzling throughout the day. 5. Rain in the night: dry and windy. 6. Heavy showers all day. 7. Rain: cleared P.M. 8. Riain. 9. Slight shower. 10. Rain in the night. 11. Frost : clear sunshine. 12. Fine day. 13. Fine A.M.: cold and windy P.M. 14. Strong cold east wind, 15. Rain and high wind, 16. Fair and fine : slight drizzle r.M. 17. Fine : shower heavy P.M. 18. Mild : growing shower, 19. Rain early A.M.: fair day. 20. Rain early : showery day. 21. Fair and fine. 22. Cold and clear. 23. Cold and clear : slight frost. 24. Cold and clear : frost A.M. 25. Rain and wind : boisterous. 26. Fair : cold, 27. Fair : clear and cold. 28. Fair A.M. : slight shower P. M. 29. Frost early. 20. Cold : a few drops of rain.

Mean temperature of the month ............................... $46^{\circ} \cdot 3$

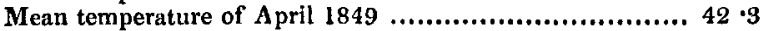

Mean temperature of April for the last twenty-eight years $.44 \cdot 3$

Rain in April 1849 ........................................... 2.52 inches.

Rain in April for twenty-three years ...................... 1.76 inch.

Sandwick Manse, Orkney.-A pril 1. Fog : damp. 2. Cloudy : rain. 3. Damp. 4. Rain. 5. Drizzle. 6. Cloudy : hazy A.M. 7. Cloudy : drops A.M. 8. Rain : cloudy. 9. Drizzle : showers. 10. Hazy : clear. 11. Drops : damp. 12. Bright : fine. 13. Cloudy : clear, 14. Clear: cloudy. 15. Drizzle: cloudy. 16. Rain : cloudy. 17. Cloudy. 18. Showers : bright : cloudy, 19. Cloudy : showers : cloudy. 20. Bright : cloudy. 21. Cloudy : drops. 22. Bright: clear. 23, 24. Cloudy, 25. Bright: clear. 26. Cloudy: drops, 27. Clear: fine, 28. Cloudy : fine. 29, 30. Drops : cloudy, 